\title{
A randomized comparative study on modified Joel- Cohen incision versus Pfannenstiel incision for cesarean section
}

\author{
Sezaryen ameliyatı için Pfannenstiel insizyonuna karşı modifiye Joel-Cohen \\ insizyonu üzerine randomize karşılaştırmalı çalışma
}

Shyama Prasad Saha ${ }^{1}$, Nabendu Bhattarcharjee ${ }^{2}$, Sabysachi Das Mahanta², Animesh Naskar², Sanjoy Kumar Bhattacharyya ${ }^{1}$

'Department of Obstetrics and Gynecology, North Bengal Medical College, Darjeeling, West Bengal, India

${ }^{2}$ Department of Obstetrics and Gynecology, R. G. Kar Medical College, Kolkata, West Bengal, India

\section{Abstract}

Objective: Pfanennstiel incision is the most commonly used incision for cesarean section, but may not be the best. This study compared the modified Joel-Cohen incision with the Pfannenstiel incision to evaluate whether techniques to open the abdomen might influence operative time, and maternal and neonatal outcomes.

Material and Methods: In a randomized comparative trial, 302 women with gestational age $>34$ weeks, requiring cesarean section, were randomly assigned to either modified Joel-Cohen incision or Pfannenstiel incision for entry into the peritoneal cavity. The primary outcome measure was total time required for performing operation and secondary outcome measures were baby extraction time, number of haemostatic procedures used in the abdominal wall, postoperative morbidity, postoperative hospital stay and neonatal outcome.

Results: Mean total operative time was significantly less in the modified Joel-Cohen group as compared to the Pfannenstiel group (29.81 vs $32.67 \mathrm{~min}, \mathrm{p}<0.0001,95 \% \mathrm{CI}=2.253$ to 3.467 ). Time taken to deliver the baby and haemostatic procedures required during operation were also significantly less in the modified Joel-Cohen group as compared to the Pfannenstiel group. Requirement of strong analgesics was higher in the Pfannenstiel group (53.64\% vs $21.85 \%, \mathrm{p}<0.0001)$. There was no statically significant difference in the incidence of postoperative wound complications but postoperative stay in hospital was significantly less in the modified Joel-Cohen group $(p=0.002)$. Neonatal outcomes were similar in both groups.

Conclusion: The modified Joel-Cohen incision for entry into peritoneal cavity during cesarean section is associated with reduced mean total operative and baby extraction times with less postoperative pain and shorter hospital stay, which may be beneficial and cost effective. (J Turkish-German Gynecol Assoc 2013; 14: 28-34)

Key words: Cesarean section, modified Joel-Cohen, Pfannenstiel, incision, operative time

Received: 06 September, 2012
Accepted: 13 December, 2012

\section{Özet}

Amaç: Pfannenstiel insizyonu sezaryen ameliyatında en yaygın kullanılan insizyondur ancak en iyisi olmayabilir. Bu çalışmada abdomeni açmak için kullanılan tekniklerin operasyon süresini, maternal ve neonatal sonuçları etkileyip etkilemediğini değerlendirmek için modifiye Joel-Cohen insizyonu Pfannenstiel insizyonu ile karşılaştırıldı.

Gereç ve Yöntemler: Randomize karşılaştırmalı çalışmada gestasyon yaşı > 34 hafta olan ve sezaryen ameliyatı gerektiren 302 kadın periton kavitesi içine giriş için modifiye Joel-Cohen insizyon veya Pfannenstiel insizyon gruplarından birine rastgele atandı. Birincil sonuç ölçütü operasyonun yapılması için gerekli olan toplam süreydi ve ikincil sonuç ölçütleri bebek çıkım zamanı, karın duvarında kullanılan hemostatik işlemlerin sayısı, postoperatif morbidite, postoperatif hastanede kalış ve neonatal akıbet idi.

Bulgular: Ortalama toplam operasyon süresi modifiye Joel-Cohen grubunda Pfannenstiel grubuna kıyasla anlamlı şekilde daha kısaydı (32.67'ye karşıllı 29.81 dk, p<0.0001, \%95 GA=2.253-3.467). Ayrıca, Pfannenstiel grubuna kıyasla modifiye Joel-Cohen grubunda bebeği doğurtma süresi ve operasyon sırasında gerekli olan hemostatik işlemler anlamlı olarak daha azdı. Güçlü analjezik gereksinimi Pfannenstiel grubunda daha yüksekti (\%21.85'e karşllı \%53.64, p<0.0001). Postoperatif yara insidansı açısından istatistiksel olarak anlamlı farklılık yoktu ancak postoperatif hastanede kalış modifiye Joel-Cohen grubunda anlamlı şekilde daha kısaydı $(\mathrm{p}=0.002)$. Neonatal akibetler her iki grupta benzerdi.

Sonuç: Sezaryen ameliyatı sırasında periton kavitesi içine giriş için modifiye Joel-Cohen insizyonu ortalama toplam operasyon süresinde ve bebek çıkım süresinde azalma, daha az postoperatif ağnı ve daha kısa hastanede kalış ile ilişkili olup faydalı ve maliyet etkin bir yöntem olabilir. (J Turkish-German Gynecol Assoc 2013; 14: 28-34)

Anahtar kelimeler: Sezaryen ameliyatı, modifiye Joel-Cohen, Pfannenstiel, insizyon, operasyon süresi

Geliş Tarihi: 06 Eylül 2012

Kabul Tarihi: 13 Aralı 2012 


\section{Introduction}

Cesarean section (CS) is the commonest major operation in women all over the world. Approximately 18.5 million cesarean sections are performed yearly worldwide. About $40 \%$ of the countries have $\mathrm{CS}$ rates $<10 \%$, about $10 \%$ have $\mathrm{CS}$ rates between 10 and 15\%, and approximately 50\% have CS rates $>15 \%$ (1). There have been different methods of opening the peritoneal cavity for Cesarean section and each has its own merits and demerits. There are vertical incisions like midline and paramedian. There are different transverse incisions like Pffanenstiel, Maylard, Cherney, Joel-Cohen, named according to the introducer.

Vertical midline incision was the preferred method for opening the abdomen during cesarean section. It has the advantage of rapid entry with ease. After that came the vertical paramedian incision. The paramedian incision is not used widely even in general surgery due to its limitations, and it is not an accepted method to use the paramedian incision for CS. Nowadays, a lower abdominal transverse incision is used for most cesarean sections. In the early days, transverse incision was avoided because it was time consuming. In 1900, classically the transverse incision was described by Pffanenstiel et al. (2). When exposure is limited and additional space is required, Maylard (3) and Cherney (4) procedures may be used. The Mouchel (5) transverse incision runs at the upper limit of the pubic hair. In the Pelosi (6) technique for caesarean delivery, the skin is cut in a low transverse fashion with a knife; the subcutaneous tissues and fascia are incised with electrocautery. Joel-Cohen et al. (7) described a transverse skin incision particularly for hysterectomy, which was subsequently adapted for cesarean sections. This incision is placed about $3 \mathrm{~cm}$ below the line joining the anterior superior iliac spines. This incision has another modification regarding opening of the peritoneum. In the classical type, the peritoneum used to be opened by finger traction laterally along with subcutaneous tissue, rectus sheath and rectus muscle. However, in the modified Joel-Cohen variety as described by Stark et al. (8), the peritoneum is not opened during separation of the structure superficial to it. Rather, it is opened in the next step by a small transverse incision in the midline which is then extended by applying finger traction both upward and downward to avoid injury to the bladder wall.

The modified Joel-Cohen incision is claimed to be associated with some immediate benefits for women undergoing cesarean delivery in comparison to the Pfannenstiel incision. Postoperative morbidity is lower following this incision as indicated by fever, postoperative pain and analgesic requirements. Although measurements are subjective, estimated intraoperative blood loss is reportedly less with the modified Joel-Cohen incision compared to Pfannenstiel and vertical incisions. The clinical significance of the reported difference (less than 100 $\mathrm{mL}$ ) in estimated blood loss is probably less important in nonanemic women but may be of greater significance in anemic women.

It is also stated that cesarean delivery using the modified JoelCohen incision takes less time than cesarean delivery by the Pfannenstiel incision. The time from skin incision to delivery of the baby and the total duration of surgery are both shorter. Less time taken for surgery may be significant in situations where there is a shortage of operation theatre facilities and staff availability. Women having the modified Joel-Cohen incision have shorter periods of hospitalization compared to the Pfannenstiel incision. Nabhan et al. (9) in his study proposed that a modified cesarean delivery technique, including Joel-Cohen incision, exteriorized full thickness suturing of the uterine incision, and non-closure of the peritoneum may reduce long-term morbidities of the procedure.

This study compared the modified Joel-Cohen incision with Pffanenstiel incision for opening abdomen in Cesarean section. The aim of the study was directed to compare the modified Joel-Cohen incision with Pfannenstiel incision with the objective to evaluate whether the technique to open the abdomen might influence operative time and maternal and neonatal outcomes.

\section{Material and Methods}

This was a prospective randomized comparative trial. We conducted the study over a period of one and half years, from July, 2010 to December, 2011 in two teaching institutions of West Bengal, India viz. R.G. Kar Medical College and Hospital, Kolkata and North Bengal Medical College and Hospital, Darjeeling, simultaneously.

Three hundred and fifty pregnant women, who were carrying more than 34 weeks of gestation, requiring cesarean sections for different indications, were assessed for enrolment in the study. After undergoing through exclusion criteria a total of 302 women were ultimately included in the study. Exclusion criteria were (a) post cesarean section pregnancy; (b) history of any other previous abdominal surgery which may have produced adhesion internally; (c) very obese patient; (d) multifetal gestation and (e) patients with a history of antepartum hemorrhage. A thorough search of the medical literature did not reveal any research that has addressed repeat cesarean section in terms of previous incision type. In our clinical experience, we had observed that there was thickening and fibrosis formation in the anterior abdominal wall in a considerable number of cases of post cesarean section pregnancy, which was a hindrance to blunt dissection of tissue plane at the time of repeat cesarean section. Haacke Karl Olaf (10), in his dissertation submitted to the University of the Witwatersrand, Johannesburg (2009), had shown that severe adhesion formation in the anterior abdominal wall detected at the time of repeat cesarean section was 51\% and 36\% following Pfannensteil and subumbilical midline skin incisions respectively during previous CS. In our view, use of the modified Joel Cohen incision in such cases is technically not a wise choice and so we excluded the post CS pregnancy cases from our study.

Three hundred and two women with a period of gestation over 34 weeks and scheduled to have a caesarean section, were included in the study. Patients were divided into two groups (A and $\mathrm{B}$ ) using a computer-generated randomization protocol having 151 women in each arm. We used a computer-generated randomization sequence to assign participants 
into two treatment groups and the allocation was concealed in sealed, sequentially numbered, brown envelopes (opaque), which had been prepared by the statistician of each centre and handed over to the sister-in-charge of the operation theatre, department of Obstetrics and Gynecology of respective Institutions. The researchers responsible for treating the pregnant women allocated the next available number on entry into the trial in the department of Obstetrics and Gynecology and the operating surgeons collected the corresponding sealed envelope directly from operation theater sister-in-charge. Four surgeons, two in each centre, were involved for performing $\mathrm{CS}$. The envelope was opened just before performing the caesarean section and the technique for entry into the peritoneal cavity was selected as per code. Because of the nature of the study, the patients were blinded but doctors responsible for performing operations were not blinded to the randomization allocation.

After allocation, relevant history and patient particulars were recorded for each patient. In group A (study group) the modified Joel-Cohen method and in group B (control group) the Pfannenstiel method were chosen for entry into the peritoneal cavity. Doctors who performed caesarean sections did not assess procedure outcomes. Assessors of the study outcomes were blinded to the techniques of caesarean sections. Before cesarean section, preoperative blood sample was taken from each patient for hemoglobin estimation.

In the Pfannenstiel group, the incision of about $15 \mathrm{~cm}$ length was made at the lowermost transverse crease $(2 \mathrm{~cm}$ above symphysis pubis) with a gentle curve upwards. After the skin was entered, the subcutaneous tissue was incised sharply with a scalpel. Once the fascia was exposed the rectus sheath, separation of rectus muscles and opening of peritoneum were carried out in the traditional way. In the modified Joel-Cohen group, a straight transverse incision deep enough to cut the cuticle of about $12 \mathrm{~cm}$ length was made $3 \mathrm{~cm}$ below the arbitrary line joining two anterior superior iliac spines. The incision in the midline was deepened with the scalpel in a short transverse cut of about $2-3 \mathrm{~cm}$ through the fat, down to the rectus sheath. A small transverse incision was made in the midline over the rectus sheath and the incision was enlarged bilaterally about $2 \mathrm{~cm}$ on either side underneath the fat and subcutaneous tissue without disturbing them. The fascial borders were gently separated caudally and cranially, using the fingers to make room for the next step. That made an oval opening of about $4 \mathrm{~cm}$ by exposing the rectus muscle underneath. Following this, the surgeon and assistant pulled the rectus muscles on their corresponding side by pushing their index and middle fingers in the midline between the rectus muscles, encircling the whole muscle bellies by smooth, balanced and increasing force. It was often necessary for both to place their other index and middle fingers over the two fingers initially placed in order to attain the force needed to make a large enough opening. The pulling force was mostly from the wrists. The parietal peritoneum was opened transversely, using the surgeon's fingers to stretch the tissues until a small hole was made. The hole was enlarged by stretching with the surgeon's two index fingers in a caudal and cranial direction simultaneously. The rest of the procedures were similar in both groups. The placenta was removed by a controlled cord traction method in both groups. The uterus was closed in two layers using No.1-0 polygygolic suture material (polygalactin 910 ) with atraumatic $40 \mathrm{~mm}$ half circle round bodied needle. An abdominal retractor was used while making an incision on the lower uterine segment and also during closure of uterine incision. The peritoneum (both visceral and parietal) was not stitched. In a few cases, haemostatic sutures using chromic catgut had to be applied (in both groups) where we could detect significant oozing or bleeding from exposed peritoneal margins or separated rectus muscles. The fascial sheath was stitched using No.1-0 polygygolic suture material. the skin in both groups was sutured by interrupted stitches using synthetic non absorbable nylon suture (2-0) with half circle $50 \mathrm{~mm}$ taper cutting needle.

The primary outcome measure was total time required for performing operation (skin to skin), and the secondary outcome measures were time taken to deliver the baby, number of haemostatic procedures used during closure of abdominal wall, requirement of postoperative analgesia, wound complication if any, postoperative stay in hospital, Apgar score at 5 minutes, birth trauma if any and appearance of scar at 12 weeks postoperative period.

From the hospital record of our institutions, we observed that $75 \%$ of women required more than 30 minutes time for completion of operation when the Pfannenstiel incision was used to enter the peritoneal cavity during cesarean section. A $25 \%$ difference in proportion of women who required more than 30 minutes time for completion of operation, between two procedures (Modified Joel-Cohen and Pfannenstiel incisions) was used to calculate the sample size having a power of 90 , setting alpha error at 0.05 . The minimum sample size thus calculated was 74 in each arm for the study to have a statistical significance.

All data entries were visually double checked by an independent second investigator. The data were analysed using MedCalc (Version 12.2.1.0, MedCalc Software) statistical software. Statistical analysis included Chi-square test, ' $z$ ' statistics and ' $\mathrm{t}$ ' test to compare the outcomes between the study group and the control group. A p-value less than 0.05 was considered as statistically significant.

The study was approved by "The Committee for Ethical Consideration and Approval for Human Research", R G Kar Medical College \& Hospital, and "The Medical Ethical Committee for Human research", North Bengal Medical College $\&$ Hospital as required by Indian law.

\section{Results}

Initially, 350 women were assessed for eligibility criteria to be included in this study. 48 women were excluded from the study due to either not meeting the inclusion criteria $(n=28)$ or refusal to participate $(n=20)$. 302 women were thus randomized into two groups (A and B) having 151 patients in each arm. Modified Joel-Cohen and Pfannensteiel incisions were used for entry into the peritoneal cavity during the caesarean section 
in group A and B respectively. Subsequently, 7 women from group A and 10 from group B were lost in follow up. Hence, 144 women in group A and 141 in group B completed the study. However, 151 women in each group who received allocation intervention were analyzed as we adopted the intention to treat protocol (Figure 1).

Demographic profiles of the patients in both groups were comparable in relation to age, parity, gestational age and indication for cesarean sections (Table 1). From Table 2, it is evident that the mean time taken to complete the operation (skin to skin) was significantly lower in the group who had the modified JoelCohen incision as compared to the Pfannenstiel incision group (29.81 $\mathrm{min}$ vs $32.67 \mathrm{~min}, \mathrm{p}<0.0001,95 \% \mathrm{CI}=2.253$ to 3.467 ). Time taken to deliver the baby and haemostatic procedures required during operation were also significantly lower in group A as compared to group B. Requirement of strong analgesics (other than paracetamol) was higher in group B (Table 3) and statistically significant when compared to group A (53.64\% vs. $21.85 \%, \mathrm{p}<0.0001)$. Postoperative fall in hemoglobin $(\mathrm{Hb})$ level and time taken for ambulation were also significantly higher in group B $(p<0.0001)$. There was no statistically significant difference in the incidence of postoperative wound complications between the two groups (Table 4) but postoperative stay in hospital was significantly shorter in group A $(p=0.002)$. Neonatal outcomes were similar in both groups (Table 5). There were no significant differences in appearance of scar at 12 weeks postsurgery (Table 6).

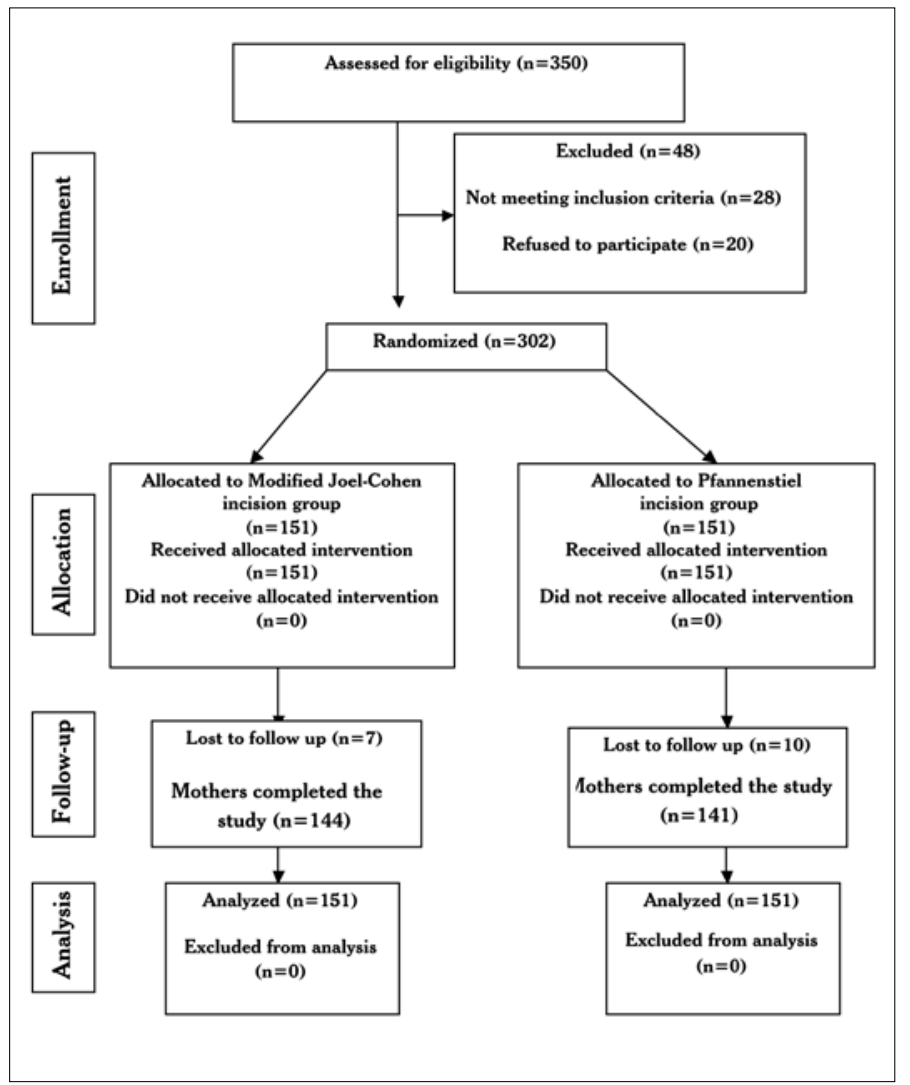

Figure 1. Patients' flow through chart.

Table 1. Demographic profile of patients

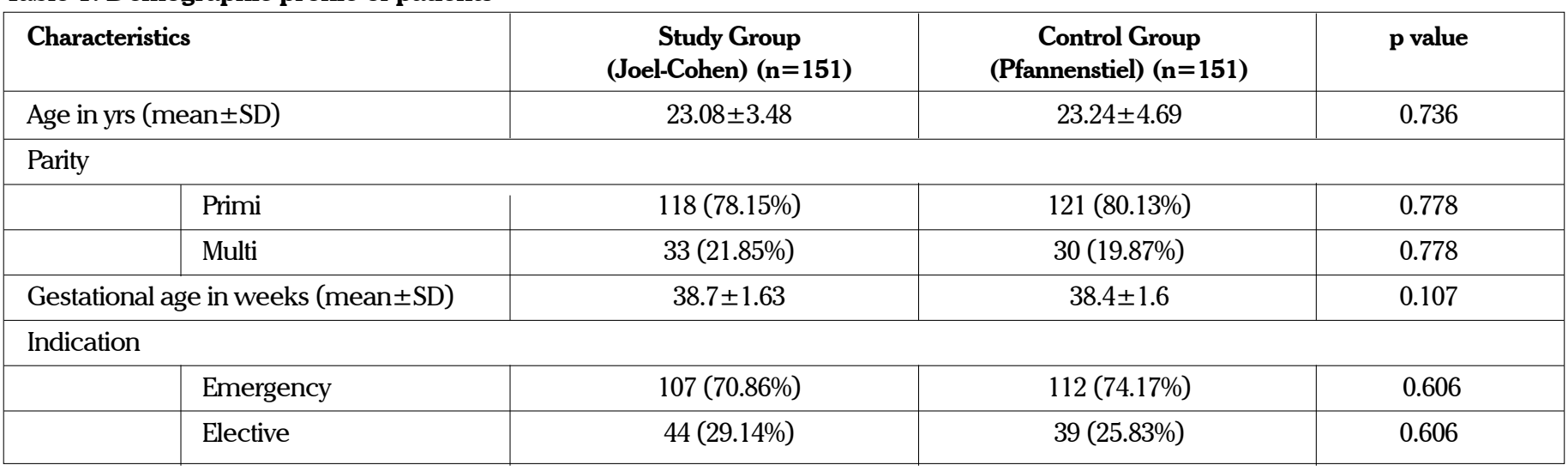

Table 2. Operative findings and outcomes

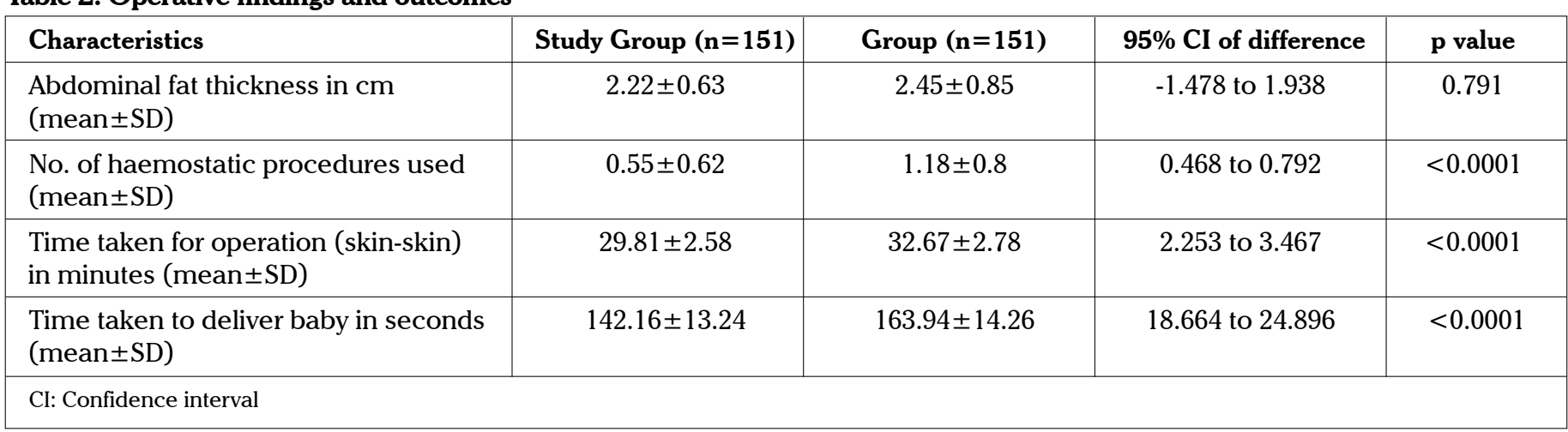


Table 3. Postoperative outcomes

\begin{tabular}{|c|c|c|c|c|}
\hline Characteristics & $\begin{array}{l}\text { Study Group } \\
(\mathrm{n}=151)\end{array}$ & $\begin{array}{l}\text { Control Group } \\
(n=151)\end{array}$ & $\begin{array}{l}\text { Odds Ratio } \\
\text { (95\% CI) }\end{array}$ & $\begin{array}{c}\text { p value } \\
\text { (95\% CI of difference) }\end{array}$ \\
\hline $\begin{array}{l}\text { Postoperative analgesic requirement } \\
\text { other than paracetamol }\end{array}$ & $33(21.85 \%)$ & 81(53.64\%) & $\begin{array}{c}0.241 \\
(0.146 \text { to } 0.399)\end{array}$ & $<0.0001$ \\
\hline $\begin{array}{l}\text { Postoperative fall in Hb after } 48 \mathrm{hrs} \\
\text { in } \mathrm{gm} / \mathrm{dl}(\mathrm{mean} \pm \mathrm{SD})\end{array}$ & $0.57 \pm 0.1$ & $0.82 \pm 0.13$ & & $\begin{array}{c}<0.0001 \\
(0.224 \text { to } 0.276)\end{array}$ \\
\hline $\begin{array}{l}\text { Time taken for ambulation in hrs } \\
\text { (mean } \pm \text { SD) }\end{array}$ & $9.6 \pm 1.64$ & $12.13 \pm 2.21$ & & $\begin{array}{c}<0.0001 \\
(2.089 \text { to } 2.971)\end{array}$ \\
\hline
\end{tabular}

Table 4. Wound complications

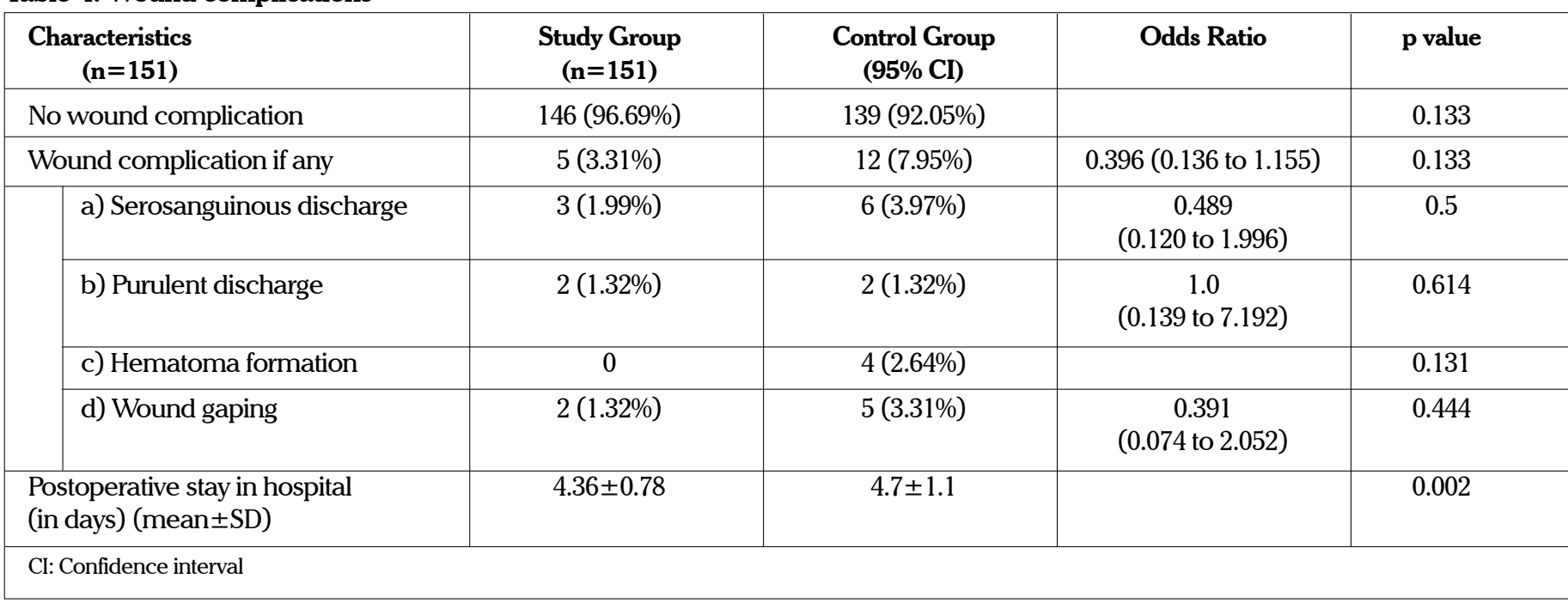

Table 5. Neonatal outcome

\begin{tabular}{|c|c|c|c|c|}
\hline Characteristics & Study Group & Control Group & $\begin{array}{c}95 \% \mathrm{CI} \\
\text { of difference }\end{array}$ & p value \\
\hline $\begin{array}{l}\text { Apgar score at } \\
5 \text { minutes }(\text { mean } \pm S D)\end{array}$ & $7.77 \pm 1.38$ & $8 \pm 1.1$ & 0.0526 to 0.513 & 0.110 \\
\hline Birth trauma if any (mean \pm SD) & Nil & Nil & & \\
\hline
\end{tabular}

Table 6. Appearance of scar at 12 weeks postoperative period

\begin{tabular}{|c|c|c|c|c|}
\hline Characteristics & Study Group $(n=151)$ & Control Group $(n=151)$ & $95 \% \mathrm{CI}$ of difference & p value \\
\hline Fine & $129(85.43 \%)$ & $122(80.79 \%)$ & $-4.287 \%$ to $13.525 \%$ & 0.356 \\
\hline Broad & $6(3.97 \%)$ & $10(6.62 \%)$ & $-2.969 \%$ to $8.437 \%$ & 0.440 \\
\hline
\end{tabular}

\section{Discussion}

In this prospective, randomized study, we compared the outcomes of cesarean section carried out by the Modified Joel-Cohen incision and Pfannenstiel incision for entering the peritoneal cavity. Different studies done at different times showed that there is some advantage in making the Modified
Joel-Cohen incision in respect of operative time, operative blood loss, postoperative pain and analgesic requirement, wound complication, postoperative hospital stay etc. Less time taken to complete the operation is of benefit in places where there is shortage of operation theater facilities or trained staff. Reduced operative blood loss is beneficial in women who are anemic due to poor nutrition or any other disease, particularly 
in countries like India. More wound complications and subsequent longer hospital stay have a significant effect in those health institutions where there is paucity of adequate beds, in addition to financial burden.

In 1998, Franchi et al. (11) did a randomized controlled trial with the objective to compare intra and postoperative morbidity between the Joel-Cohen incision followed by nonclosure of pelvic and parietal peritoneum $(n=149)$ as an alternative to the Pfannenstiel incision with peritonealization $(n=150)$ at cesarean section. A shorter median opening time and a shorter median operative time $(p<0.01)$ were observed in the former group.

In 2008 Hofmeyr et al. (12) searched the Cochrane Pregnancy and Childbirth Group's Trials Register (August 2007), the Cochrane Central Register of Controlled Trials (The Cochrane Library 2007, Issue 3) and found the Joel-Cohen incision for cesarean section compared with Pfannenstiel incision was associated with: less blood loss, (five trials, 481 women; weighted mean difference (WMD) $-64.45 \mathrm{~mL}$; 95\% confidence interval (CI) -91.34 to $-37.56 \mathrm{~mL}$ ); shorter operating time (five trials, 581 women; WMD -18.65 ; $95 \%$ CI -24.84 to -12.45 minutes) and shorter time from skin incision to birth of the baby (five trials, 575 women; WMD -3.84 minutes; $95 \%$ CI -5.41 to -2.27 minutes). In our study, we found that there was significant difference in mean time taken for completion of cesarean section between the two methods, 29.81 minutes for modified Joel-Cohen incision vs 32.67 minutes for Pfannenstiel incision ( $p<0.0001,95 \%$ $\mathrm{CI}=2.253$ to 3.467$)$. These findings were similar to the findings of studies by Wallin et al. (13) (1999) and Ferrari et al. (14) (2001). In 2002, Franchi et al. (15) in their study did not find any difference in total operative time between the two groups for performing cesarean section by using either the Joel-Cohen or Pfannenstiel incisions. We also observed that the mean time taken for baby extraction (from skin incision to delivery of baby) was significantly less in cases of the Modified Joel- Cohen incision group compared to Pfannenstiel incision group in our study (142.16 sec vs. $163.94 \mathrm{sec}, \mathrm{p}<0.0001,95 \% \mathrm{CI}=18.664$ to 24.896). Franchi M et al. (15) (2002) and Zienkowicz et al. (16) (2000) had similar opinions in their studies.

The Cochrane Pregnancy and Childbirth Group's Trials Register (17), when searched by Mathai M and Hofmeyr GJ in 2007, showed reduced estimated blood loss for the Joel-Cohen incision as compared to the Pfannenstiel incision (weighted mean difference $(\mathrm{WMD})=58.00,95 \% \mathrm{CI}=-108.51$ to $-7.49 \mathrm{~mL})$. In our study we could not directly measure the blood loss from abdominal wall incision sites due to mixing of blood with amniotic fluid and uterine blood. However, indirect methods, like the number of hemostatic procedures used and postoperative fall in hemoglobin concentration after $48 \mathrm{hrs,} \mathrm{were} \mathrm{used}$ to assess the blood loss. We found that there was significantly less use of hemostatic procedures in case of the Modified JoelCohen incision compared to Pfannenstiel incision $(\mathrm{p}<0.0001$, $95 \% \mathrm{CI}=0.468$ to 0.792 ). Similarly there was a significant fall in postoperative hemoglobin level in the control group compared to the study group ( $\mathrm{p}<0.0001,95 \% \mathrm{CI}=0.224$ to 0.276$)$.

Data analysis in our study showed that the Modified Joel-Cohen method needed less use of stronger analgesics in the postoper- ative period to relieve pain compared to the Pfannenstiel method which was statistically significant $(\mathrm{RR}=0.407,95 \% \mathrm{CI}=0.291$ to $0.570, \mathrm{p}<0.0001$ ). Postoperative discomfort at the abdominal incision site was evidently less in the study group as seen from time taken for ambulation of patient when both groups were compared $(p<0.0001)$. Mathai et al. (16) on searching The Cochrane Pregnancy and Childbirth Group's Trials Register in 2007, observed that Joel-Cohen incision was associated with lower total dose of analgesia in the first 24 hours $(\mathrm{WMD}=0.89$, $95 \% \mathrm{CI}=-1.19$ to -0.59$)$ and increased time to the first dose of analgesia ( $\mathrm{WMD}=0.80,95 \% \mathrm{CI}=0.12$ to 1.48 ) compared to the Pfannenstiel group.

Franchi et al. (11), in their study, compared intra- and postoperative morbidity between the two techniques. No difference was found in terms of intraoperative complications, proportion of patients who required transfusion, endometritis, sepsis, febrile morbidity, and urinary tract infections. A higher rate of wound infections was found in the Pfannenstiel group than that in the Joel-Cohen group (14 of 150 (9.3\%) vs. 2 of $149(1.3 \%)$, respectively, $\mathrm{p}<0.01$ ). Mathai et al. (16) on searching Cochrane Pregnancy and Childbirth Group's Trials Register, found that there was a $65 \%$ reduction in reported postoperative morbidity (Relative Risk $=0.35,95 \% \mathrm{CI}=0.14$ to 0.87 ) and short postoperative hospital stay for the mother with the Joel-Cohen incision $(\mathrm{WMD}=1.50,95 \% \mathrm{CI}=-2.16$ to -0.84$)$. In our study, although in absolute number, wound complication was greater in cases of the Pfannenstiel incision, that was not statistically significant. However, postoperative hospital stay was significantly shorter in the modified Joel-Cohen group. Regarding appearance of scar after 12 weeks, we did not find any comparative study. In our study we found no significant difference in the nature of scar when both groups were compared.

In the study conducted by Franchi et al. (10) no difference was found in the neonatal neurodevelopmental assessment at 6 months of age in relation to the abdominal incision performed. In our study, we did not follow the neonates after their discharge from hospital, but immediate neonatal outcomes did not vary with the type of incisions.

This study could analyse a reasonably adequate sample size for comparison of feto-maternal outcomes between modified JoelCohen and Pfannenstiel incisions for perfoming cesarean sections. In this study, there was not a single case of discontinued intervention after randomization and only a few cases were lost during follow up in both groups (7 in group A and 10 in group B). We also adopted the intention to treat principle for analyzing results. The only weakness of this study was non measurement of actual blood loss from the abdominal incision sites.

The modified Joel-Cohen incision for entry into the peritoneal cavity during cesarean section is associated with reduced mean total operative and baby extraction times, with less postoperative pain and shorter hospital stay which may be beneficial and cost effective.

\section{Acknowledgments}

The contribution of Mrs Uma Bhattacharjee, Ward Sister, District Hospital, Chinsura, West Bengal, India who has been of immense help in giving the article its present form, espe- 
cially in correcting the grammatical errors and punctuations, is acknowledged with thanks.

\section{Conflict of interest}

No conflict of interest was declared by the authors.

\section{References}

1. Gibbons L, Belizan J M, Lauer JA, Betran AP, Merialdi M, Althabe F. The Global Numbers and Costs of Additionally Needed and Unnecessary Caesarean Sections Performed per Year: Overuse as a Barrier to Universal Coverage. World Health Report; 2010. Background Paper, 30.

2. Pfannenstiel JH. Uber die vortheile des suprasymphysaren fascienguerschnitt fur die. Gynaekologischen koeliotomien. Samml klin vortr gynaekol (Leipzig) Nr 268 1900; 97: 1735.

3. Maylard AE. Direction of abdominal incision. Br Med J 1907; 2: 895901.

4. Cherney LS. A modified transverse incision for low abdominal operations. Surg Gynecol Obstet 1941; 72: 92-5.

5. Mouchel J. Transverse trans-rectus abdominis incision in gynaecological and obstetrical surgery. 673 cases (author's transl). Nouv Presse Med 1981; 10: 413-5.

6. Wood RM, Simon H, Oz AU. Pelosi-type vs. traditional cesarean delivery. A prospective comparison. J Reprod Med 1999; 44: 788-95.

7. Joel-Cohen S. Abdominal and vaginal hysterectomy. New techniques based on time and motion studies. William Heinemann Medical Books. London: 1972. pp. 170.
8. Holmgren G, Sjoholm L, Stark M. The misgav ladach method for cesarean section: method description. Acta Obstet Gynecol Scand 1999; 78: 615-21. [CrossRef]

9. Nabhan AF. Long-term outcomes of two different surgical techniques for cesarean. Int J Gynaecol Obstet 2008; 100: 69-75. [CrossRef]

10. Haacke, Karl Olaf. Midline versus Pfannenstiel incision scars in repeat caesarean sections. Electronic Theses. 2009.

11. Franchi M, Ghezzi F, Balestreri D, Beretta P, Maymon E, Miglierina $\mathrm{M}$, et al. A randomized clinical trial of two surgical techniques for cesarean section. Am J Perinatol 1998; 15: 589-94. [CrossRef]

12. Hofmeyr GJ, Mathai M, Shah A. Techniques for caesarean section. Cochrane Database Syst Rev 2008: CD004662

13. Wallin G, Fall O. Modified Joel-Cohen technique for caesarean section. A prospective randomised trial. Acta Obstetricia et Gynecologica Scandinavica 1997; 76: 24.

14. Ferrari AG, Frigerio LG, Candotti G, Buscaglia M, Petrone M, Taglioretti A, et al. Can Joel-Cohen incision and single layer reconstruction reduce cesarean section morbidity? Int J Gynaecol Obstet 2001; 72: 135-43. [CrossRef]

15. Franchi M, Ghezzi F, Raio L, Di Naro E, Miglierina M, Agosti M, et al. Joel-Cohen or Pfannenstiel incision at cesarean delivery: does it make a difference? Acta Obstet Gynecol Scand 2002; 81: 1040-6. [CrossRef]

16. Zienkowicz Z, Suchocki S, Sleboda H, Bojarski M. Cesarean section by the Misgav Ladach + with the abdominal opening surgery by the Joel-Cohen method. Ginekol Pol 2000; 71: 284-7.

17. Dodd JM, Anderson ER, Gates S. Surgical techniques for uterine incision and uterine closure at the time of caesarean incision. Cochrane Database Syst Rev 2008: CD004732. 